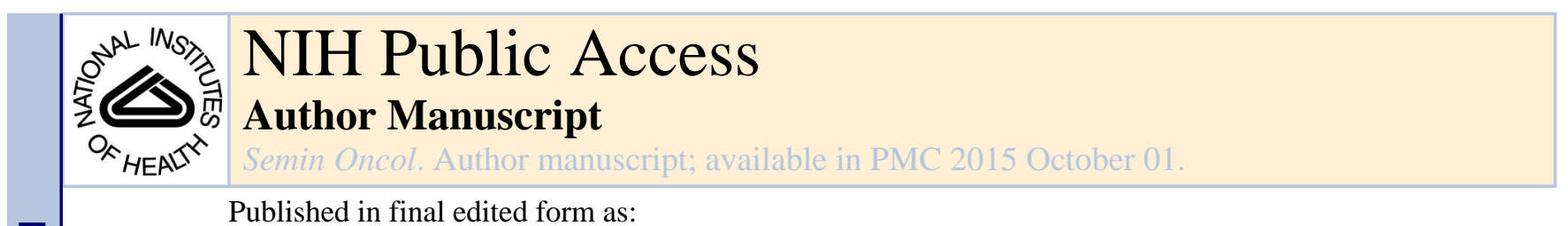

Published in final edited form as:

Semin Oncol. 2014 October ; 41(5): 661-666. doi:10.1053/j.seminoncol.2014.08.005.

\title{
From Monoclonal Antibodies to Chimeric Antigen Receptors for the Treatment of Human Malignancies
}

\author{
Ignazio Caruana1, Iulia Diaconu1 ${ }^{1}$, and Gianpietro Dotti ${ }^{1,2,3,{ }^{*}}$ \\ ${ }^{1}$ Center for Cell and Gene Therapy, Baylor College of Medicine \\ ${ }^{2}$ Department of Medicine, Baylor College of Medicine \\ ${ }^{3}$ Department of Immunology, Baylor College of Medicine
}

\begin{abstract}
Monoclonal antibodies (mAbs) and their directly derived cell-based application known as chimeric antigen receptors (CARs) ensue from the need to develop novel therapeutic strategies that retain high anti-tumor activity, but carry reduced toxicity compared to conventional chemoand radio-therapies. In this concise review article we will summarize the application of antibodies designed to target antigens expressed by tumor cells, and the transition from these antibodies to the generation of CARs.
\end{abstract}

\section{Development of monoclonal antibodies for cancer treatment}

The use of mAbs in cancer patients was pioneered in 1980 by Nadler et al in a patient with relapsed lymphoma(1). Twelve years later the US Food and Drug Administration (FDA) approved the first therapeutic monoclonal antibody (mAb) (Orthoclone OKT3®) for the treatment of patients with acute transplant rejection(2). In the last 30 years more than a dozen of mAbs specific for different antigens of interest for human malignancies have been developed, received regulatory approval and marketed. Although Rituximab (anti-CD20 $\mathrm{mAb}$ ) is the most extensively used, over 2900 clinical trials based on the administration of mAbs have been reported and many others are currently ongoing in cancer patients (ClinicalTrials.gov). In addition, the development of mAbs experienced a significant technical evolution, from the first production of murine, rabbit and chimeric mAbs to the new generation of humanized mAbs that lead to lower immunogenicity and therefore longer half-life in vivo(3).

These therapeutic mAbs are designed to recognize a tumor antigen and cause cell death through various mechanisms. Briefly, mAbs can directly induce apoptosis of tumor cells or

(c) 2014 Elsevier Inc. All rights reserved

*Address Correspondences to: Gianpietro Dotti, Center for Cell and Gene Therapy, Baylor College of Medicine, 6621 Fannin St/ MC 3-3320, Houston, TX 77030, Phone: (832) 824-6891, Fax: (832) 825-4732, gdotti@ bcm.edu.

All the authors equally contribute to the review article and are listed in alphabetic order.

Publisher's Disclaimer: This is a PDF file of an unedited manuscript that has been accepted for publication. As a service to our customers we are providing this early version of the manuscript. The manuscript will undergo copyediting, typesetting, and review of the resulting proof before it is published in its final citable form. Please note that during the production process errors may be discovered which could affect the content, and all legal disclaimers that apply to the journal pertain. 
indirectly eliminate them by recruiting various immune cells with cytotoxic properties (monocytes, macrophages and natural killer cells) (phenomenon know as antibodydependent cell mediated cytotoxicity, ADCC) or by activating the complement cascade (complement dependent cytotoxicity, CDC)(4;5). In addition, mAbs have been modified to carry tumoricidal substances, such as chemotherapeutic agents, radioisotopes, toxins or small molecule(6;7). Some of these antibodies such as Brentuximab vedotin (SGN-35) have been approved by the FDA and are in use for the treatment of CD30 ${ }^{+}$Hodgkin's lymphoma(8). Finally, a new group of mAbs called bispecific T-cell enhancing (BITE) antibodies have been developed to simultaneously target two antigens, one on tumor cells and the other one on effector $\mathrm{T}$ cells to recruit and co-localize immunological active cells to the tumor $(9 ; 10)$. The best example of this specific application is Blinatumomab (MT103) (CD19- and CD3-specific $\mathrm{Ab}$ ) that has promoted numerous clinical responses in patients with non-Hodgkin's lymphoma(11;12) and acute lymphoblastic leukemia $(13 ; 14)$.

\section{From mAbs to the generation of antibody-based effector $\mathrm{T}$ cells}

The concept of directly coupling the antigen-specificity of a mAb with the effector function of T lymphocytes has been pioneered by Eshhar et al. in 1989(15). This approach completely transformed the dogma of T-cell specificity from MHC-peptide-restricted recognition to "MHC-independent-antigen" recognition. This new class of antibody-based molecules used to engineer $\mathrm{T}$ lymphocytes has been labeled T-bodies or more recently chimeric antigen receptor (CARs). Table 1 summarizes the antigens that have been targeted with mAbs and are now targeted with CARs, and those directly targeted via CAR-mediated approaches in clinical trials.

CARs are generated by fusing an extracellular antigen-recognition moiety with intracellular signaling endo-domains, and are anchored to the cell membrane through a trans-membrane domain. The antigen recognition moiety is derived from a $\mathrm{mAb}$ in the form of a single-chain $\mathrm{Ab}$ fragment (scFv) that includes the variable heavy $\left(\mathrm{V}_{\mathrm{H}}\right)$ and light $\left(\mathrm{V}_{\mathrm{L}}\right)$ chains. The signaling endo-domain is derived from the $\mathrm{CD} 3 \zeta$ chain or the chain of the high-affinity $\operatorname{IgE}$ Fc receptor (FceRI). When expressed by $\mathrm{T}$ lymphocytes, the $\mathrm{scFv}$ determines the CAR antigen specificity and allows $\mathrm{T}$ cells to engage the antigen expressed by tumor cells in a MHC-independent manner. After binding to the target, cross-linked CAR molecules activate the endo-domain signaling, thus inducing the lysis of the engaged target cells through granzyme-B and perforin-pathways (15).

A more advanced generation of these molecules aims at further engineering these molecules to recapitulate the costimulatory events that must occur upon TCR triggering to fully activate T lymphocytes. Signaling domains derived from T-cell-costimulatory receptors are thus directly incorporated in tandem with the CD3 chain. Intracytoplasmic signaling domains of CD28, CD134 (OX40), CD137 (4-1BB), inducible costimulatory (ICOS), CD27, DAP10 or CD244 (2B4) in various combinations have been used to construct $2^{\text {nd }}$ and $3^{\text {rd }}$ generation CARs (16-22) (Figure 1). 


\section{MAbs and CAR-T cells: advantages and disadvantages}

The development of new technologies for the construction of mAbs and in particular the generation of chimeric and humanized mAbs has enormously improved safety and efficacy of these agents, and justifies their current large use in clinical trials in cancer patients. Humanized mAbs are characterized indeed by drastically reduced immunogenicity compared to mouse-originated $\mathrm{mAbs}$, reducing the incidence of anaphylactic reactions and prolonging the half life of these molecules after infusion into the patients(3).

Objective drawbacks exit that limit the efficacy of mAbs and render the combination of the antigen specificity of a mAb with the biological properties of $\mathrm{T}$ lymphocytes as achieved with CARs of high relevance. For instance, tumor cells can escape the toxic effects of mAbs if the targeted antigen has dim or heterogeneous expression, or if the mAb binds to the antigen in a suboptimal fashion thus failing to recruit the effector cells that ultimately promote the elimination of tumor cells $(23 ; 24)$. Finally, since mAbs are generally administered via intravenous infusion, physical barriers in vivo, such as endothelial cells and extracellular matrix, can drastically reduce the effective biodistribution of mAbs to the tumor cells(24). In contrast, CAR-engineered T cells, while preserving the same antigen specificity of mAbs, have the multiple advantages of triggering the elimination of tumor cells with low antigen expression, the tissue biodistribution property of cellular vehicles and the self amplification property of the immune cells.

\section{Targets with low antigen expression}

Monoclonal Abs and CAR-T cells, even when they share the same antigen specificity, use different mechanisms to eliminate the target cells. Specifically, CAR-T cells directly lyse the tumor cells upon engaging the antigen using the physiologic cytotoxic machinery of killer cells. High functional T-cell-receptor can recognize few peptide/HLA-complexes(25). Similarly, CARs ectopically expressed at certain density by $\mathrm{T}$ lymphocytes trigger cytotoxicity against target antigens expressed at relatively low levels by tumor cells $(18 ; 26)$. For this specific property, CAR-T cells appear superior to mAbs as target cells with low antigen expression can escape recognition by mAbs, as high numbers of antigen molecules are required for $\mathrm{mAbs}$ to efficiently activate either the ADCC or the complement cascade $(27 ; 28)$. This desirable characteristic of CAR-T cells has however its own caveats. CARmediated recognition of cells with low antigen expression raises the concern of "on target" but "off tumor" toxicity if the antigen is shared at certain levels by the normal compartment from which the tumor originates or by other normal tissues(29;30).

\section{Biodistribution and tumor environment}

Biodistribution of mAbs within the tumor environment, particularly in solid tumors, has been one of the major challenges. Monoclonal Abs are particularly effective in lymphoid malignancies. In early clinical studies with Rituximab, objective regressions were reported not only in patients with residual disease, but also in patients presenting with large lymph adenopathies(31). In the case of solid tumors, mAbs almost invariably fail in patients with large tumor burden(32). Studies specifically designed to measure the biodistribution of mAbs in solid tumors showed that a very small fraction of the mAb infused intravenously 
$(<0.1 \%$ per gram of tissue) can be detected within the tumor(33). This limited biodistribution is attributed to a series of physical hurdles that mAbs infused intravenously must overcome to reach the tumor cells. The endothelial barrier, with its thigh endothelial junctions, hinders the passage of macromolecules such as mAbs (34). After extravasion, mAbs subsequently encounter interstitial and epithelial barriers that reduce their perfusion(35). In contrast to $\mathrm{mAbs}$, $\mathrm{T}$ lymphocytes have the physiologic capacity to extravasate(36), and travel within tissues as they can actively use chemokine gradients(37) and release proteolytic enzymes to degrade components of the extracellular matrix(38). Thus, CAR-T cells are anticipated to use the same properties which are instead lacking in the procedure of passive administration of mAbs. Up to now the clinical experience with CAR-T cells in lymphoid malignancies targeting the CD19 antigen mirrors the clinical experience with Rituximab since robust clinical responses have been reported(39-42). Although the clinical experience with CAR-T cells in solid tumors remains very limited, initial objective clinical responses have been reported in neuroblastoma(43;44). However, as several preclinical models using CAR-T cells anticipated, additional engineering of $\mathrm{T}$ cells, such as manipulations of chemokine receptors expressed by the T cells(45-47), may be required to optimize the trafficking of CAR-T cells within the tumor environment.

\section{Self amplification and persistence}

Due to their still relatively short half life, mAbs requires multiple administrations to be effective in cancer patients. The enormous advantage of adoptively transferred $\mathrm{T}$ cells is their capacity to expand in vivo upon transfer and persist long term if a memory pool is established. Previous clinical trials in which ex vivo expanded virus-specific cytotoxic T lymphocytes were infused in patients with Epstein-Barr-virus-related post transplant lymphomas clearly demonstrated that this outcome definitely occurs as these cells can be detected for more than 12 years after adoptive transfer (48). Engineered CAR-T cells seem to maintain the same promise. Although the observation is still limited, the incorporation of the 4-1BB costimulatory endodomain supports a robust and functional long term engraftment of CD19-specific CAR-T cells as documented by the prolonged B-cell aplasia (more than 18 months) occurring in patients with detectable CAR signal after a single administration of gene modified T cells(39). CD28 costimulation, although functional in term of expansion and antitumor activity, appears however a bit more transient and not followed by a comparable extended T-cell survival(40-42;49). However, additional studies and higher numbers of patients enrolled in clinical studies are needed to draw definitive conclusions. Furthermore, the effect of these CAR-T cell costimulations in the context of solid tumors remains to be elucidated.

\section{Conclusions and future directions}

After some initial negative clinical experiences, CAR-T cell therapies represent now a very solid approach and a real hope for the future of cancer immunotherapies. Because CARbased therapies are strictly linked from mAb-based therapies, at least in term of antigen specificity, we need to seek whether CAR-T cells offer sufficient advantages to justify the need for a personalized medicine, since CAR-T cells need to be manufactured for each single patient while mAbs are off-the shelf reagents. Preliminary evidences are, at least in 
part, in favor of suggesting the superior role of CAR-T cells to mAbs, since the former can promote self amplification and sustained effects, and can recognize tumor cells with antigen expression at levels that can elude mAb's recognition. However, whether adoptively transferred CAR-T cells are superior to mAbs in term of biodistribution to the tumor still requires a robust demonstration although essential to develop effective strategies especially for solid tumors. The proposed engineering of CAR-T cells to optimize their trafficking to the tumor environment represents a potential way to achieve this desired effect. Finally, greater efficacy frequently comes with toxicities, and in the specific case of CAR-T cells, these toxicities cannot be necessarily anticipated from the previous and safe use of a $\mathrm{mAb}$ specific for the same target due to the intrinsic functional activity of $\mathrm{T}$ cells to which the CAR molecule are engaged. Thus a very careful selection of the target antigen must be used in case of CAR-T-cell based therapies.

\section{Acknowledgments}

This work was supported in part by R01 CA142636 National Institutes of Health-NCI, W81XWH-10-10425 Department of Defense and Technology/Therapeutic Development Award, SCOR grant from the Leukemia and Lymphoma Society, P50CA126752 SPORE in Lymphoma.

\section{Reference List}

1. Nadler LM, Stashenko P, Hardy R, Kaplan WD, Button LN, Kufe DW, Antman KH, Schlossman SF. Serotherapy of a patient with a monoclonal antibody directed against a human lymphomaassociated antigen. Cancer Res. 1980; 40:3147-3154. [PubMed: 7427932]

2. Cosimi AB, Colvin RB, Burton RC, Rubin RH, Goldstein G, Kung PC, Hansen WP, Delmonico FL, Russell PS. Use of monoclonal antibodies to T-cell subsets for immunologic monitoring and treatment in recipients of renal allografts. N. Engl. J. Med. 1981; 305:308-314. [PubMed: 6454075]

3. Oldham RK, Dillman RO. Monoclonal antibodies in cancer therapy: 25 years of progress. J. Clin. Oncol. 2008; 26:1774-1777. [PubMed: 18398141]

4. Maloney DG. Follicular NHL: from antibodies and vaccines to graft-versus-lymphoma effects. Hematology. Am. Soc. Hematol. Educ. Program. 2007:226-232. [PubMed: 18024634]

5. Reichert JM, Valge-Archer VE. Development trends for monoclonal antibody cancer therapeutics. Nat. Rev. Drug Discov. 2007; 6:349-356. [PubMed: 17431406]

6. Kreitman RJ, Squires DR, Stetler-Stevenson M, Noel P, FitzGerald DJ, Wilson WH, Pastan I. Phase I trial of recombinant immunotoxin RFB4(dsFv)-PE38 (BL22) in patients with B-cell malignancies. J. Clin. Oncol. 2005; 23:6719-6729. [PubMed: 16061911]

7. Maloney D, Morschhauser F, Linden O, Hagenbeek A, Gisselbrecht C. Diversity in antibody-based approaches to non-Hodgkin lymphoma. Leuk. Lymphoma. 2010; 51(Suppl 1):20-27. [PubMed: 20815760]

8. Younes A, Bartlett NL, Leonard JP, Kennedy DA, Lynch CM, Sievers EL, Forero-Torres A. Brentuximab vedotin (SGN-35) for relapsed CD30-positive lymphomas. N. Engl. J. Med. 2010; 363:1812-1821. [PubMed: 21047225]

9. Hoelzer D, Gokbuget N. Chemoimmunotherapy in acute lymphoblastic leukemia. Blood Rev. 2012; 26:25-32. [PubMed: 21958552]

10. Klinger M, Brandl C, Zugmaier G, Hijazi Y, Bargou RC, Topp MS, Gokbuget N, Neumann S, Goebeler M, Viardot A, et al. Immunopharmacologic response of patients with B-lineage acute lymphoblastic leukemia to continuous infusion of T cell-engaging CD19/CD3-bispecific BiTE antibody blinatumomab. Blood. 2012; 119:6226-6233. [PubMed: 22592608]

11. Bargou R, Leo E, Zugmaier G, Klinger M, Goebeler M, Knop S, Noppeney R, Viardot A, Hess G, Schuler M, et al. Tumor regression in cancer patients by very low doses of a T cell-engaging antibody. Science. 2008; 321:974-977. [PubMed: 18703743] 
12. Topp MS, Kufer P, Gokbuget N, Goebeler M, Klinger M, Neumann S, Horst HA, Raff T, Viardot A, Schmid M, et al. Targeted therapy with the T-cell-engaging antibody blinatumomab of chemotherapy-refractory minimal residual disease in B-lineage acute lymphoblastic leukemia patients results in high response rate and prolonged leukemia-free survival. J. Clin. Oncol. 2011; 29:2493-2498. [PubMed: 21576633]

13. Nagorsen D, Bargou R, Ruttinger D, Kufer P, Baeuerle PA, Zugmaier G. Immunotherapy of lymphoma and leukemia with T-cell engaging BiTE antibody blinatumomab. Leuk. Lymphoma. 2009; 50:886-891. [PubMed: 19455460]

14. Nagorsen D, Kufer P, Baeuerle PA, Bargou R. Blinatumomab: a historical perspective. Pharmacol. Ther. 2012; 136:334-342. [PubMed: 22940266]

15. Eshhar Z, Waks T, Gross G, Schindler DG. Specific activation and targeting of cytotoxic lymphocytes through chimeric single chains consisting of antibody-binding domains and the gamma or zeta subunits of the immunoglobulin and T-cell receptors. Proc. Natl. Acad. Sci. U. S. A. 1993; 90:720-724. [PubMed: 8421711]

16. Maher J, Brentjens RJ, Gunset G, Riviere I, Sadelain M. Human T-lymphocyte cytotoxicity and proliferation directed by a single chimeric TCRzeta /CD28 receptor. Nat. Biotechnol. 2002; 20:70-75. [PubMed: 11753365]

17. Finney HM, Lawson AD, Bebbington CR, Weir AN. Chimeric receptors providing both primary and costimulatory signaling in T cells from a single gene product. J. Immunol. 1998; 161:27912797. [PubMed: 9743337]

18. Vera J, Savoldo B, Vigouroux S, Biagi E, Pule M, Rossig C, Wu J, Heslop HE, Rooney CM, Brenner MK, et al. T lymphocytes redirected against the kappa light chain of human immunoglobulin efficiently kill mature B lymphocyte-derived malignant cells. Blood. 2006; 108:3890-3897. [PubMed: 16926291]

19. Imai C, Mihara K, Andreansky M, Nicholson IC, Pui CH, Geiger TL, Campana D. Chimeric receptors with $4-1 \mathrm{BB}$ signaling capacity provoke potent cytotoxicity against acute lymphoblastic leukemia. Leukemia. 2004; 18:676-684. [PubMed: 14961035]

20. Pule MA, Straathof KC, Dotti G, Heslop HE, Rooney CM, Brenner MK. A chimeric T cell antigen receptor that augments cytokine release and supports clonal expansion of primary human $\mathrm{T}$ cells. Mol. Ther. 2005; 12:933-941. [PubMed: 15979412]

21. Carpenito C, Milone MC, Hassan R, Simonet JC, Lakhal M, Suhoski MM, Varela-Rohena A, Haines KM, Heitjan DF, Albelda SM, et al. Control of large, established tumor xenografts with genetically retargeted human T cells containing CD28 and CD137 domains. Proc. Natl. Acad. Sci. U. S. A. 2009; 106:3360-3365. [PubMed: 19211796]

22. Jena B, Dotti G, Cooper LJ. Redirecting T-cell specificity by introducing a tumor-specific chimeric antigen receptor. Blood. 2010; 116:1035-1044. [PubMed: 20439624]

23. Leibowitz MS, Nayak JV, Ferris RL. Head and neck cancer immunotherapy: clinical evaluation. Curr. Oncol. Rep. 2008; 10:162-169. [PubMed: 18377830]

24. Christiansen J, Rajasekaran AK. Biological impediments to monoclonal antibody-based cancer immunotherapy. Mol. Cancer Ther. 2004; 3:1493-1501. [PubMed: 15542788]

25. Purbhoo MA, Sutton DH, Brewer JE, Mullings RE, Hill ME, Mahon TM, Karbach J, Jager E, Cameron BJ, Lissin N, et al. Quantifying and imaging NY-ESO-1/LAGE-1-derived epitopes on tumor cells using high affinity T cell receptors. J. Immunol. 2006; 176:7308-7316. [PubMed: 16751374]

26. Ahmed N, Ratnayake M, Savoldo B, Perlaky L, Dotti G, Wels WS, Bhattacharjee MB, Gilbertson RJ, Shine HD, Weiss HL, et al. Regression of experimental medulloblastoma following transfer of HER2-specific T cells. Cancer Res. 2007; 67:5957-5964. [PubMed: 17575166]

27. Capone PM, Papsidero LD, Chu TM. Relationship between antigen density and immunotherapeutic response elicited by monoclonal antibodies against solid tumors. J. Natl. Cancer Inst. 1984; 72:673-677. [PubMed: 6583450]

28. Sung C, Shockley TR, Morrison PF, Dvorak HF, Yarmush ML, Dedrick RL. Predicted and observed effects of antibody affinity and antigen density on monoclonal antibody uptake in solid tumors. Cancer Res. 1992; 52:377-384. [PubMed: 1728409] 
29. Morgan RA, Yang JC, Kitano M, Dudley ME, Laurencot CM, Rosenberg SA. Case report of a serious adverse event following the administration of $\mathrm{T}$ cells transduced with a chimeric antigen receptor recognizing ERBB2. Mol. Ther. 2010; 18:843-851. [PubMed: 20179677]

30. Lamers CH, Sleijfer S, Vulto AG, Kruit WH, Kliffen M, Debets R, Gratama JW, Stoter G, Oosterwijk E. Treatment of metastatic renal cell carcinoma with autologous T-lymphocytes genetically retargeted against carbonic anhydrase IX: first clinical experience. J. Clin. Oncol. 2006; 24:e20-e22. [PubMed: 16648493]

31. McLaughlin P, Grillo-Lopez AJ, Link BK, Levy R, Czuczman MS, Williams ME, Heyman MR, Bence-Bruckler I, White CA, Cabanillas F, et al. Rituximab chimeric anti-CD20 monoclonal antibody therapy for relapsed indolent lymphoma: half of patients respond to a four-dose treatment program. J. Clin. Oncol. 1998; 16:2825-2833. [PubMed: 9704735]

32. Riethmuller G, Schneider-Gadicke E, Schlimok G, Schmiegel W, Raab R, Hoffken K, Gruber R, Pichlmaier H, Hirche H, Pichlmayr R, et al. German Cancer Aid 17-1A Study Group. Randomised trial of monoclonal antibody for adjuvant therapy of resected Dukes' C colorectal carcinoma. Lancet. 1994; 343:1177-1183. [PubMed: 7909866]

33. Goldenberg DM. Targeting of cancer with radiolabeled antibodies. Prospects for imaging and therapy. Arch. Pathol. Lab Med. 1988; 112:580-587. [PubMed: 3288167]

34. Dejana E, Corada M, Lampugnani MG. Endothelial cell-to-cell junctions. FASEB J. 1995; 9:910918. [PubMed: 7615160]

35. Jain RK, Baxter LT. Mechanisms of heterogeneous distribution of monoclonal antibodies and other macromolecules in tumors: significance of elevated interstitial pressure. Cancer Res. 1988; 48:7022-7032. [PubMed: 3191477]

36. Shulman Z, Cohen SJ, Roediger B, Kalchenko V, Jain R, Grabovsky V, Klein E, Shinder V, Stoler-Barak L, Feigelson SW, et al. Transendothelial migration of lymphocytes mediated by intraendothelial vesicle stores rather than by extracellular chemokine depots. Nat. Immunol. 2012; 13:67-76. [PubMed: 22138716]

37. Masopust D, Schenkel JM. The integration of T cell migration, differentiation and function. Nat. Rev. Immunol. 2013; 13:309-320. [PubMed: 23598650]

38. de Mestre AM, Staykova MA, Hornby JR, Willenborg DO, Hulett MD. Expression of the heparan sulfate-degrading enzyme heparanase is induced in infiltrating CD4+ T cells in experimental autoimmune encephalomyelitis and regulated at the level of transcription by early growth response gene 1. J. Leukoc. Biol. 2007; 82:1289-1300. [PubMed: 17656651]

39. Kalos M, Levine BL, Porter DL, Katz S, Grupp SA, Bagg A, June CH. T cells with chimeric antigen receptors have potent antitumor effects and can establish memory in patients with advanced leukemia. Sci. Transl. Med. 2011; 3:95ra73.

40. Brentjens RJ, Riviere I, Park JH, Davila ML, Wang X, Stefanski J, Taylor C, Yeh R, Bartido S, Borquez-Ojeda O, et al. Safety and persistence of adoptively transferred autologous CD19targeted $\mathrm{T}$ cells in patients with relapsed or chemotherapy refractory B-cell leukemias. Blood. 2011; 118:4817-4828. [PubMed: 21849486]

41. Cruz CR, Micklethwaite KP, Savoldo B, Ramos CA, Lam S, Ku S, Diouf O, Liu E, Barrett AJ, Ito $\mathrm{S}$, et al. Infusion of donor-derived CD19-redirected virus-specific T cells for B-cell malignancies relapsed after allogeneic stem cell transplant: a phase 1 study. Blood. 2013; 122:2965-2973. [PubMed: 24030379]

42. Kochenderfer JN, Rosenberg SA. Treating B-cell cancer with T cells expressing anti-CD19 chimeric antigen receptors. Nat. Rev. Clin. Oncol. 2013; 10:267-276. [PubMed: 23546520]

43. Pule MA, Savoldo B, Myers GD, Rossig C, Russell HV, Dotti G, Huls MH, Liu E, Gee AP, Mei Z, et al. Virus-specific $\mathrm{T}$ cells engineered to coexpress tumor-specific receptors: persistence and antitumor activity in individuals with neuroblastoma. Nat. Med. 2008; 14:1264-1270. [PubMed: 18978797]

44. Louis CU, Savoldo B, Dotti G, Pule M, Yvon E, Myers GD, Rossig C, Russell HV, Diouf O, Liu $\mathrm{E}$, et al. Antitumor activity and long-term fate of chimeric antigen receptor-positive $\mathrm{T}$ cells in patients with neuroblastoma. Blood. 2011; 118:6050-6056. [PubMed: 21984804]

45. Di Stasi A, De Angelis B, Rooney CM, Zhang L, Mahendravada A, Foster AE, Heslop HE, Brenner MK, Dotti G, Savoldo B. T lymphocytes coexpressing CCR4 and a chimeric antigen 
receptor targeting CD30 have improved homing and antitumor activity in a Hodgkin tumor model. Blood. 2009; 113:6392-6402. [PubMed: 19377047]

46. Craddock JA, Lu A, Bear A, Pule M, Brenner MK, Rooney CM, Foster AE. Enhanced tumor trafficking of GD2 chimeric antigen receptor T cells by expression of the chemokine receptor CCR2b. J. Immunother. 2010; 33:780-788. [PubMed: 20842059]

47. Kershaw MH, Wang G, Westwood JA, Pachynski RK, Tiffany HL, Marincola FM, Wang E, Young HA, Murphy PM, Hwu P. Redirecting migration of T cells to chemokine secreted from tumors by genetic modification with CXCR2. Hum. Gene Ther. 2002; 13:1971-1980. [PubMed: 12427307]

48. Heslop HE, Slobod KS, Pule MA, Hale GA, Rousseau A, Smith CA, Bollard CM, Liu H, Wu MF, Rochester RJ, et al. Long-term outcome of EBV-specific T-cell infusions to prevent or treat EBVrelated lymphoproliferative disease in transplant recipients. Blood. 2010; 115:925-935. [PubMed: 19880495]

49. Savoldo B, Ramos CA, Liu E, Mims MP, Keating MJ, Carrum G, Kamble RT, Bollard CM, Gee AP, Mei Z, et al. CD28 costimulation improves expansion and persistence of chimeric antigen receptor-modified T cells in lymphoma patients. J. Clin. Invest. 2011; 121:1822-1826. [PubMed: 21540550] 
A.

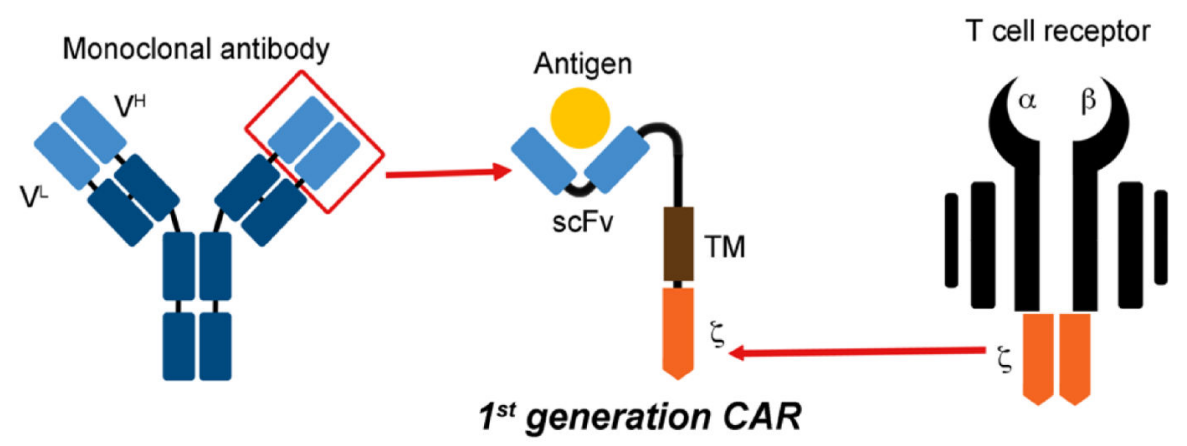

B.

C.
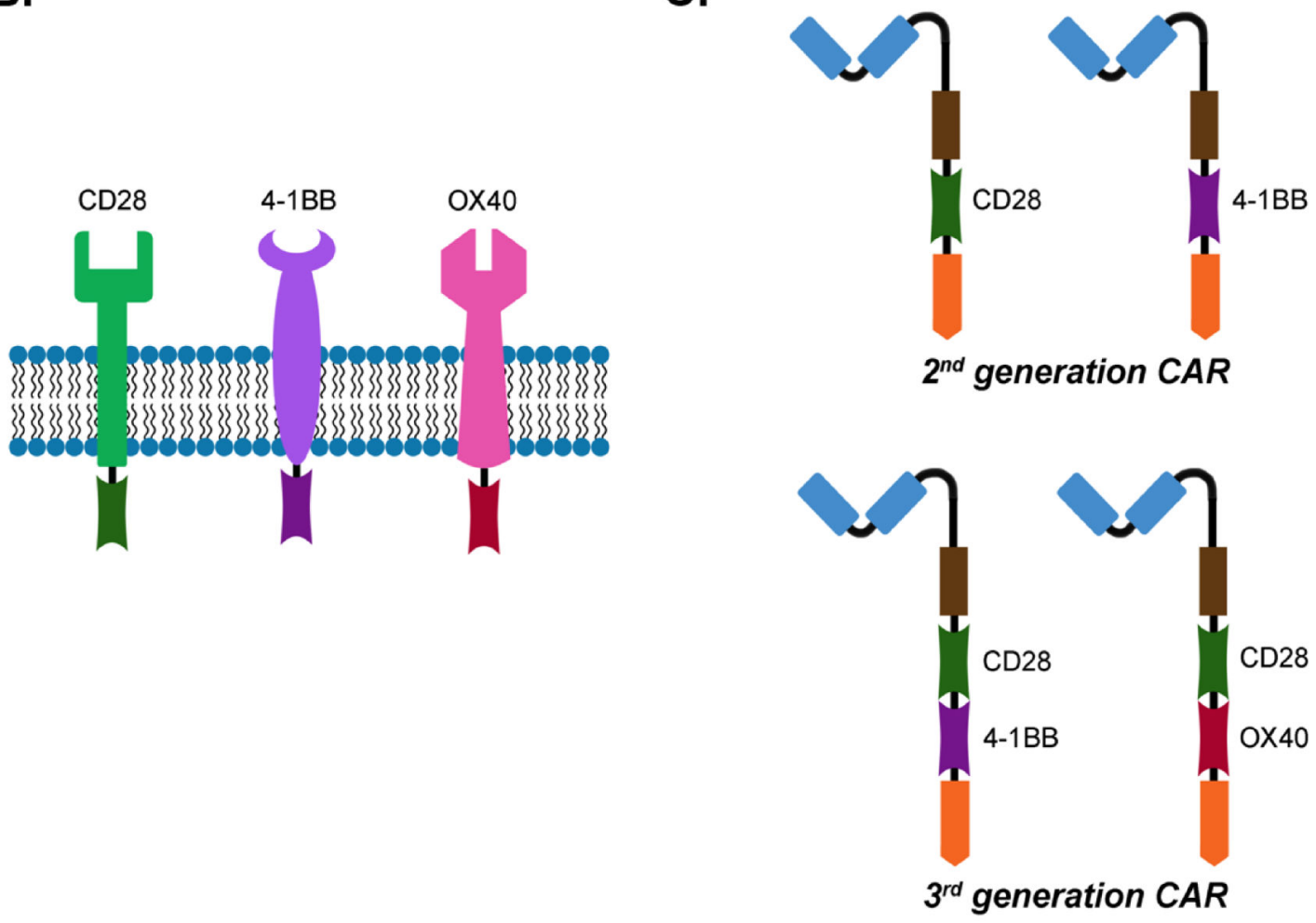

Figure 1.

Schematic representation of a Chimeric Antigen Receptor. Panel A describes the generation of the $\mathrm{scFv}$ moiety from a mAb and its fusion with the -chain of the T-cell receptor. Panel B illustrates the native form of co-stimulatory endodomains. Panel C illustrates the schematic representation of $1^{\text {st }}, 2^{\text {nd }}$, and $3^{\text {rd }}$ generation CARs including the intracytoplasmic domains of either CD28 or 4-1BB or the combination of CD28-OX40 or CD28-4-1BB. 
Table 1

\begin{tabular}{|c|c|c|c|c|}
\hline & \multicolumn{4}{|c|}{ Clinical Trials } \\
\hline & \multicolumn{2}{|l|}{ Antibodies } & \multicolumn{2}{|l|}{ CAR } \\
\hline & Name & $\mathbf{N}$ & Vector & $\mathbf{N}$ \\
\hline \multirow{8}{*}{ CD19 } & MEDI-551 & 8 & ScFv.CD19.CD3ל & 7 \\
\hline & SGN-CD19A & 2 & EBV-CTLs ScFv.CD19.CD3ל & 1 \\
\hline & SAR3419 & 5 & 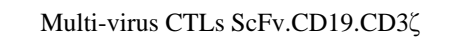 & 1 \\
\hline & - & --- & 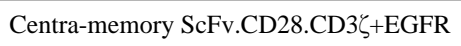 & 1 \\
\hline & - & --- & $\begin{array}{l}\text { T cells and EBV-CTLs } \\
\text { ScFv.CD19.CD28.CD3ל }\end{array}$ & 1 \\
\hline & --- & --- & 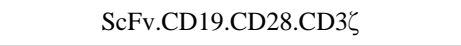 & 5 \\
\hline & - & - & 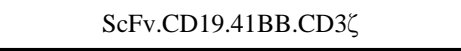 & 7 \\
\hline & - & - & 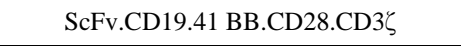 & 1 \\
\hline $\begin{array}{l}\text { Kappa light } \\
\text { chain of Igs }\end{array}$ & --- & --- & 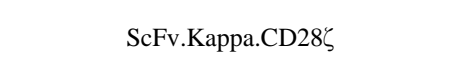 & 1 \\
\hline \multirow{7}{*}{ CD20 } & Ibritumomab tiuxetan & 87 & ScFv.CD20.41BB $\zeta$ & 1 \\
\hline & Obinutuzumab & 21 & ScFv.CD20.CD28.41BB $\zeta$ & 1 \\
\hline & Ofatumumab & 95 & --- & --- \\
\hline & Rituximab & 1231 & --- & --- \\
\hline & Tositumomab & 85 & --- & --- \\
\hline & Veltuzumab & 8 & - & - \\
\hline & AME 133 & 2 & - & - \\
\hline \multirow{2}{*}{ CD30 } & Brentuximab vedotin & 60 & ScFv.CD30 & 1 \\
\hline & - & - & 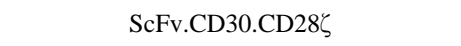 & 1 \\
\hline \multirow{2}{*}{ CD33 } & Gemtuzumab ozogamicin * & 57 & ScFv.CD33.41BB $\zeta$ & 1 \\
\hline & SGN-CD33A & 1 & -- & -- \\
\hline \multirow{5}{*}{$\begin{array}{l}\text { CD340 (Her2) - } \\
\text { EGFR2 }\end{array}$} & Pertuzumab & 58 & ScFv.HER $2 \zeta$ & 1 \\
\hline & Trastuzumab & 599 & 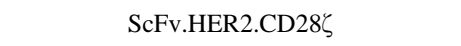 & 1 \\
\hline & Trastuzumab emtansine & 37 & $\begin{array}{c}\text { ScFv.HER2.CD28 } \zeta+\mathrm{TGF} \beta \text { resist in EBV- } \\
\text { CTLs }\end{array}$ & 1 \\
\hline & & & ScFv.HER2.41BB $\zeta$ & 1 \\
\hline & & & ScFv.HER2.CD28 3 in CMV-CTLs & 1 \\
\hline \multirow{3}{*}{ EGFR- Her1 } & Nimotuzumab & 35 & ScFv.EGFRvIN.CD28.41BB $\zeta$ & 1 \\
\hline & Panitumumab & 151 & ScFv.EGFR $\zeta$ & 1 \\
\hline & Cetuximab & 584 & ScFv.EGFR.41BB $\zeta$ & 1 \\
\hline PSMA & Capromab & 2 & ScFv.antiPSMA.CD28 $\zeta$ & 1 \\
\hline \multirow{2}{*}{ CEA } & Besilesomab (Europe) & $?$ & ScFv.antiCEA.MFEל & 1 \\
\hline & --- & --- & ScFv.antiCEA.CD28ל & 1 \\
\hline \multirow[b]{2}{*}{ GD2 } & $3 \mathrm{~F} 8$ & 30 & ScFv.GD2.CD28.OX40ל.iCasp9 & 1 \\
\hline & Ch14.18 & 12 & $\begin{array}{l}\text { ScFv.GD2.CD28.OX40ל.iCasp9 in VZV- } \\
\text { CTLs }\end{array}$ & 1 \\
\hline
\end{tabular}




\begin{tabular}{|c|c|c|c|c|}
\hline & \multicolumn{4}{|c|}{ Clinical Trials } \\
\hline & \multicolumn{2}{|c|}{ Antibodies } & \multicolumn{2}{|l|}{ CAR } \\
\hline & Name & $\mathbf{N}$ & Vector & $\mathbf{N}$ \\
\hline T4 & - & - & ScFv.T4.CD28ל & 1 \\
\hline LewisY & --- & --- & ScFv.antiY.CD28ל & 1 \\
\hline
\end{tabular}

In bold are shown mAbs that are FDA approved;

Withdrawal from Market in 2010. 